外傷性破裂を契機に発見され，血清 CA19-9および CA125高值を呈した小児脾類表皮囊胞の 1 例

三豊総合病院外科 ${ }^{11}$, 岡山大学大学院医蒾学総合研究科腫場・胸部外科 ${ }^{2)}$

山本 寛 斉12) 宇高徹 総 ${ }^{11}$ 徳毛 誠 樹"

水田稔1 白川和 豊" ${ }^{11}$ 屋崇”

今回われわれは外傷による破裂を契機に発見され, 血清 CA19-9およびCA125の高值 を呈した小归脾類表皮豪胞の 1 例を経験したので報告する。症例は15歳, 男児. 腹部打 撲による腹痛にて来院した．腹部 CTにて著明な腹腔内貯留液と破裂した巨大な脾軎胞 を認めた。脾動脈造影では明らかな血管外漏出は認めなかったため一旦保存的治療を行 った. 血清 CA19-9，CA125はそれそれ214.5U/ml，221.5U/ml と高值を示し，他臟器 に異常を認めなかったため脾類表皮壤胞と術前診断し，脾缄摘出術を施行した．㖶胞内 のCEA，CA19-9，CA125はそれぞれ383.9ng/ml，>5000.0U/ml, 3041.1U/ml といず れも高值であった。病理組織では襄胞内面は重層扁平上皮により裹打ちされており，脾 類表皮覇胞と診断した，免疫特殊染色(CEA，CA19-9，CA125）ては，同上皮に一致し て陽性所見を認めた。術後経過は良好て，術後 1 力月での血清 CA19-9, CA125は正常化 していた.

索引用語 : epidermoid cy'st of the spleen, CA19-9, CA125

\section{緒 言}

脾類表皮襄胞は比較的稀な疾患とされているが，近 年の画像診断の進歩により報告例は増加している。 た脾䧶胞症例において, carbohydrate antigen19-9(以 下，CA19-9と略記)などの腫演マーカーが高值を示す 例愉である.今回われわれは外傷による破裂を契機 に発見され，血清CA19-9おょび carbohydrate antigen125(以下,CA125と略記)の高值を呈した小児 脾類表皮蘘胞の 1 例を経験したので若干の文献的考察 を加えて報告する。

患者：15歳，男児.

\section{症 例}

主訴: 腹部打撲, 腹痛。

家族歴：特記すべきことなし．

既往歴：6歳時虫垂切除術施行. 外傷の既往なし.

現病歴: 平成13年10月11日, 体育の授業中に腹部を 強打し, 救急車にて当院に般送された. 腹部 CTにて

2003年 7 月 7日受付 2003 年 9 月 26 日採用

〈所属施設住所〉

厂769-1695 香川県三豊郡豊浜町姫浜708
脾蕞胞破裂と診断され、入院となった.

現症：身長 $165 \mathrm{~cm}$ ，体重 $72 \mathrm{~kg}$ ，血圧 $107 / 76 \mathrm{mmHg}$, 体温 $37.1^{\circ} \mathrm{C}$ ．意識は清明で神経症状なし．眼瞼・眼球 結膜に筫血・黄疸なし、胸部には異常所見は認めなか つたが，腹部はやや膨隆し，圧痛と反跳痛を認めたが 明らかな腫瘤は触知しなかった。

入院時血液検查所見 : 白血球数 $13,450 / \mu 1$ と軽度の 上昇を認めたが，他は特に異常を認めなかった。腫蔇 マーカーでは CA19-9 214.5U/ml, CA125 221.5U/ml と高値であったが, carcinoembryonic antigen(以下， CEA と略記）は $0.8 \mathrm{ng} / \mathrm{ml}$ と正常であった.

腹部 CT 所見（入院時）：大量の腹腔内貯留液を認

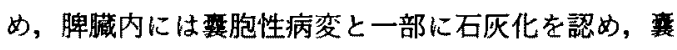
胞壁の途絶が認められ，脾政胞破裂と診断した（図 1 a).

腹水穿刺にて血性の排液を認めたため, 緊急脾動脈 造影を施行した。

脾動脈造影所見：造影㘊の明らかな血管外への漏出 や腫湯濃染像はなかったが, 腫場による血管の伸暴が 認められた．睡㰾に流入していると思われる血管に選 択的に TAEを施行した。 

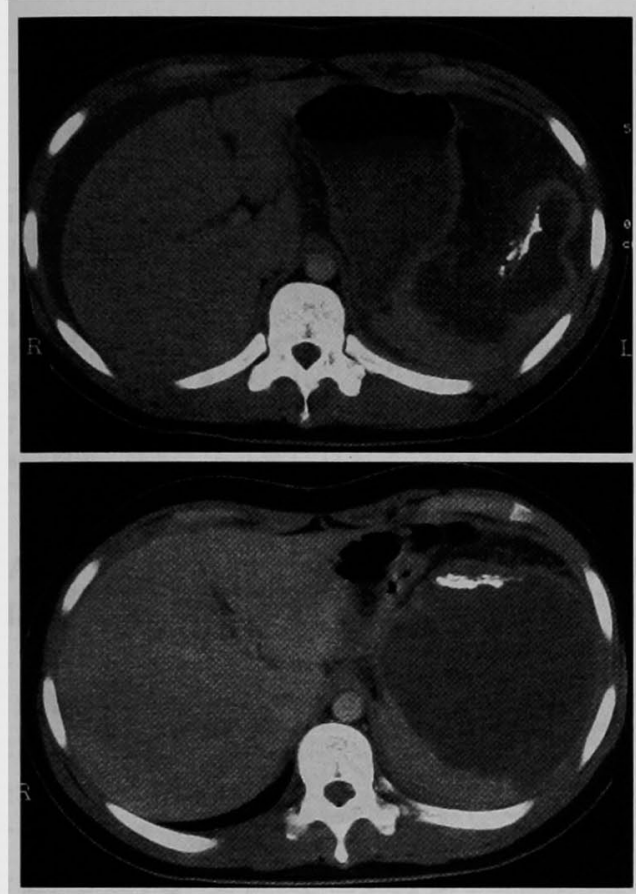

図 1 腹部 CT：a）著明な腹腔内貯留液と破裂した

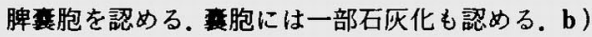
一週間後。腹腔内貯留液は消失し，破裂した車胞は 本来の形状に戻っている.

$\frac{a}{b}$

全身状態が安定していたため保存的に治療を行っ た。

腹部 CT 所見 (一週間後)：腹腔内貯留液は消失し， 破裂した襄胞性腫湐は本来の形状に戻っていた（図 1 b). 脾䁍は TAE の影響で一部に necrosis を認めた。 腹部超音波検查所見：脾臓内に, 約 $10 \times 8 \mathrm{~cm}$ 大て 辺縁が凹凸不整である低エコー性腫瘤を認めた。腫瘤 の内部エコーはほほ均一であった。

腹部 MRI 所見：脾臓内の襄胞は T 1 強調, T 2 強 調のいずれにおいても高信号であり, 襄胞内出血が示 唆された（図 2 ). 。た他藏器の異常は認めなかった。

以上の所見より，CA19-9およびCA125産生性の脾 亚胞，特に過去の報告例から脾類表皮謽胞が強く疑わ れると術前診断した，再破裂の可能性があることや， 悪性腫瘍を完全に否定できないことより，平成 13 年 10 月29日手術を施行した。

手術所見：腹部正中切開にて開腹したところ, 漿液 性の腹水 $100 \mathrm{ml}$ を認めた。正常脾実質を温存しようと 試みるも大部分が腫瘍であったため, 脾摘出術を施行
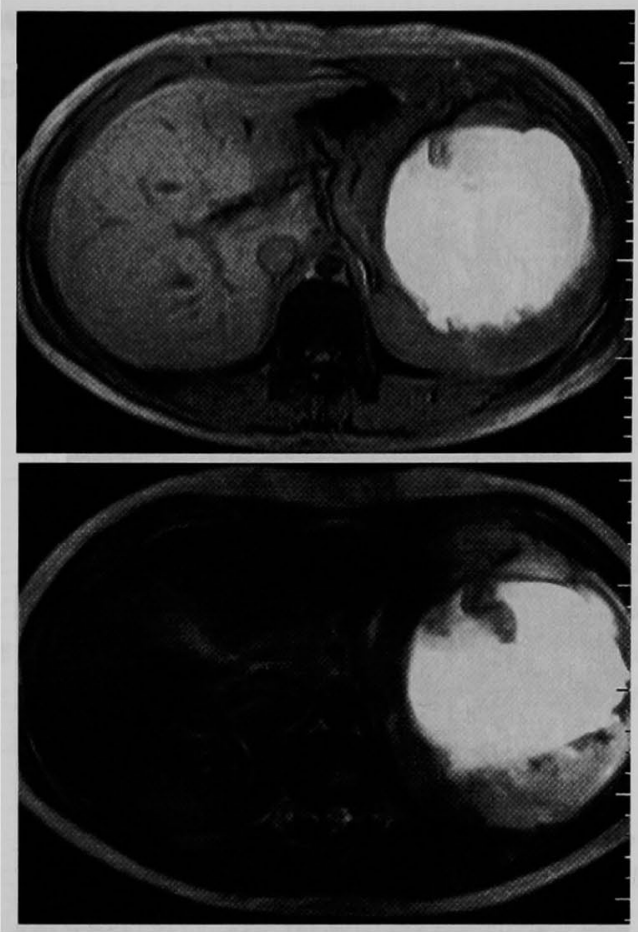

図 2 腹部 $\operatorname{IRI}(\mathbf{a} ： \mathrm{~T} 1, \mathrm{~b} ： \mathrm{~T} 2) ＼mathrm{~ ： 脾 缄 内 の 腫 瘍 ~}$ は T 1 強調, T 2 強調のいずれにおいても高信号で あり, 襄胞内出血が示唆された。 $\frac{\mathrm{a}}{\mathrm{b}}$

した、副脾を認めたのでこれを大網内に自家移植した。 腹水中の CEA，CA19-9，CA125はそれぞれ <0.5ng/ $\mathrm{ml}, 24.0 \mathrm{U} / \mathrm{ml}, 229.8 \mathrm{U} / \mathrm{ml}$ であった.

摘出標本所見：大きさは $17.5 \times 16 \times 11 \mathrm{~cm} て ゙$, 重量 は $1,640 \mathrm{~g}$ (内容液を含む) であった（図 3 ）．正常脾は ほとんど認めなかった，割面では梁柱形成を認めた。 壤胞内容液は黒褐色で，内容液の CEA，CA19-9， $\mathrm{CA} 125$ 值はそれぞれ383.9ng/ml, >5000.0U/ml, $3041.1 \mathrm{U} / \mathrm{ml}$ であった。腹水の培養検査は negative で，細胞診は class I であった。

病理組織所見：軎胞内面は重層扁平上皮により裏打 ちされており，類表皮垔胞と診断した，免疫特殊染色 ではCA19-9陽性であった(図4)）。また CEA，CA125 にも陽性であった。

術後経過：特に合併症を認めず，術後16日目に退院 した. 術後 1 力月での血清 CEA, CA19-9, CA125はそ れぞれ0.8ng/ml, $8.3 \mathrm{U} / \mathrm{ml}, 15.7 \mathrm{U} / \mathrm{ml}$ であった。

$$
\text { 考 察 }
$$

脾顀胞は1829年 Andral ${ }^{1}$ が最初に剖検例を報告し 


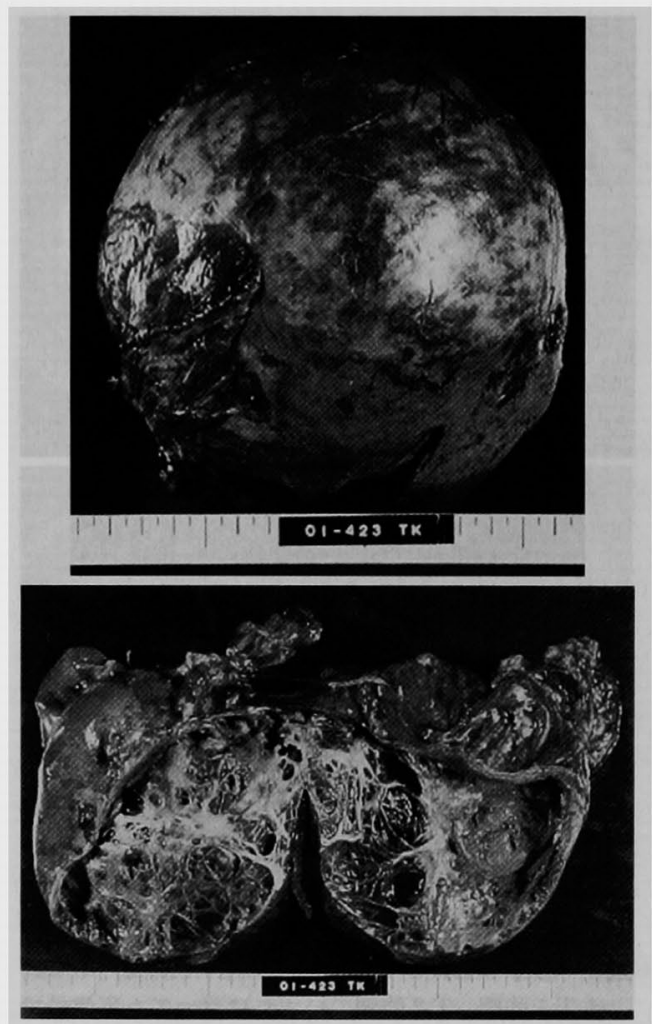

図 3 摘出標本 : 大きさは $17.5 \times 16 \times 11 \mathrm{~cm}$ で，重量 は $1,640 \mathrm{~g}$ (内容液を含む) であった。童胞内容液は 黒褐色で，割面ては梁柱形成を認めた。

摘出標本 摘出標本 (割面)

ているが，本邦でも画像診断の進歩により，現在まで に600例以上の報告がある.脾哓胞はさまざまな分類が あるが, McClure ら の分類が広く用いられている。こ の分類では襄胞内面の細胞列の有無により真性襄胞と 仮性衰胞に分類され，さらに真性表胞は上皮性，内皮 性, 寄生虫性に，仮性谼胞は出血性，炎症性等に分類 される.上皮性の真性唭胞のうち，毛根，汗腺などの 皮成付属器が認められるものは類皮莀胞で, 皮间付属 器が認められないものが類表皮莀胞である.

脾莍胞の中でもCA19-9産生性のものは近年報告が 增えているが，本邦報告例はわれわれが検索し得た限 りでは自験例も含めて64例あり，そのうち15歳以下の 小児例は 8 例であった(表 1 )。，小児脾哓胞は女児に多 いとの報告がある ${ }^{3 / 4)}$ が，今回の CA19-9産生例では男 児 5 例，女児 3 例と男児に多く，一方成人56例では男 性13例，女性43例と女性に多かった。主訴は小児例，

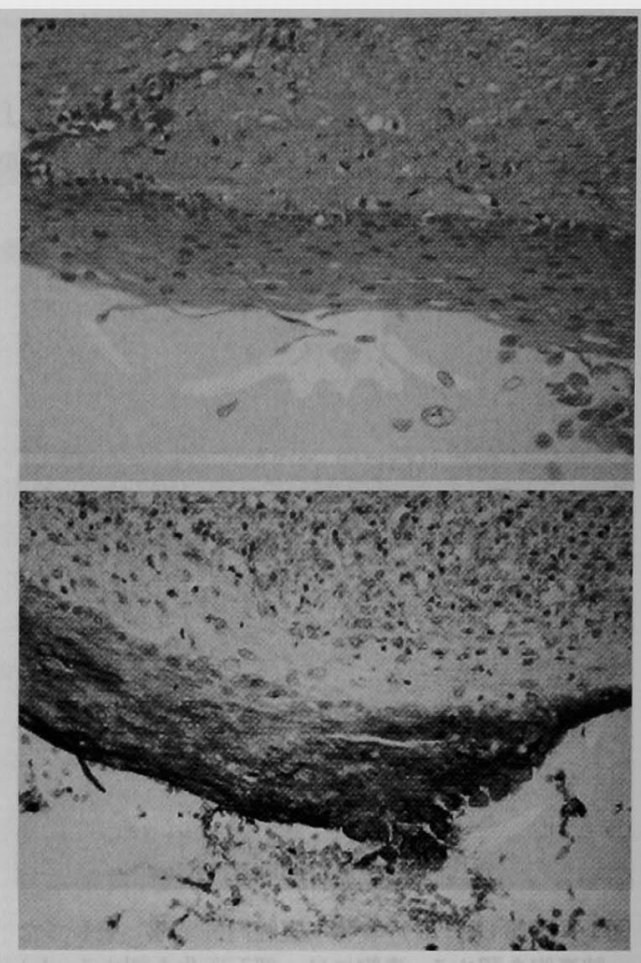

图 4 病理組織

a HE 染色 (対物20倍)：哄胞内面は重層扁平上 皮により襄打ちされており，類表皮黄胞と診断し た.

b CA19-9 免疫染色（対物20倍）：免疫染色では CA19-9陽性であった。

成人例ともに左上腹部腫瘤, 左上腹部痛, 消化器症状 などが多いが小児の場合は自覚症状に乏しく偶然に発 見されることも多い3). 自験例でも以前に上腹部痛な どの症状は認めていない，自験例では外傷により囊胞 が破裂し，腹膜刺激症状で発症したが，このような症 例は過去の集計例を見ても少ない"．亳胞の最大径は 記載のある 6 例で 6 〜 $23 \mathrm{~cm}$ (平均 $15.75 \mathrm{~cm}$ ) て，血清 CA19-9および蓑胞内CA19-9は 8例全てで高值を呈 していた，病理組織では類表皮葶胞が 5 例，類皮毫胞 が 1 例であり，残りの 2 例も上皮性襄胞であった。一 方成人56例では記載のあるものでは類表皮婁胞を中心 に上皮性暴胞が44例を占めたが内皮性毫胞としてリン パ管腫 3 例を認めた。

襄胞被覆細胞の免疫染色にて CA19-9が陽性所見を 示す報告が多く,自験例では免疫特殊染色にてCA19-9, 
表 1 CA19-9産生性小肾脾基胞本邦報告例

\begin{tabular}{|c|c|c|c|c|c|c|c|c|c|c|c|c|}
\hline \multirow[b]{2}{*}{ 報告者 } & \multirow[b]{2}{*}{ 年度 } & \multirow[b]{2}{*}{ 年齢 } & \multirow[b]{2}{*}{ 性 } & \multirow[b]{2}{*}{$\begin{array}{c}\text { 最大经 } \\
(\mathrm{cm})\end{array}$} & \multicolumn{2}{|c|}{ 血中 } & \multicolumn{2}{|c|}{ 賞胞内 } & \multirow[b]{2}{*}{ 手術 } & \multirow[b]{2}{*}{ 病理組織 } & \multirow{2}{*}{\multicolumn{2}{|c|}{ 兔疫染色 }} \\
\hline & & & & & $\begin{array}{l}\text { CA19 } \\
(\mathrm{U} / \mathrm{ml})\end{array}$ & $\begin{array}{c}\text { CEA } \\
(\mathrm{ng} / \mathrm{ml})\end{array}$ & $\begin{array}{l}\text { CA19- } \\
(\mathrm{U} / \mathrm{ml})\end{array}$ & $\begin{array}{c}\mathrm{CEA} \\
(\mathrm{ng} / \mathrm{ml})\end{array}$ & & & & \\
\hline 1.松川I & 1990 & 14 & 女 & 23 & 225 & & $>240000$ & & 脾摘 & 2 層の立方上皮 & + & \\
\hline 2. 島多 & 1993 & 9 & 女 & 10 & 860 & 1.9 & $>10000$ & 630 & 脾摘 & 類表皮真胞 & + & + \\
\hline 3.渡井 & 1995 & 15 & 男 & 18 & 110 & 正常 & 200000 & & 脾摘 & 類表皮真胞 & & \\
\hline 4.松田 & 1995 & 14 & 女 & 6 & 83 & & 120000 & & 脾部分切除 & 重層扁平上皮 & & \\
\hline 5.松尾 & 1997 & 13 & 男 & & 236 & & 24000 & & 脾摘 & 類皮萁胞 & & \\
\hline 6. 䎟 & 2000 & 12 & 男 & & 5180 & & $>10000$ & & 脾部分切除 & 類表皮筑胞 & + & \\
\hline 7.上拉 & 2001 & 12 & 男 & 20 & 109.9 & 1.1 & 859000 & & 睓摘 & 類表皮衰胞 & + & \\
\hline 8. 自医例 & 2003 & 15 & 男 & 17.5 & 214.5 & 0.8 & $>5000$ & 383.9 & 脾摘 & 類表皮蕉胞 & + & + \\
\hline
\end{tabular}

CA125，CEA のいずれもが陽性であった。また，塞胞 摘出後は, 高值であった血清 CA19-9, CA125は正常化 していた。

血清 CA19-9は膵荿, 胆道系の癌や, 子宮癌, 卵策癌, また胆石，総胆管結石，膵炎などの良性疾患でも高值 を示す5゙た，高 CA19-9血症を呈する疾患を鑑別猃断 する際は注意が必要である，脾亳胞で高 CA19-9血症 を呈する機序については，島多ら゙によると售胞被覆 細胞より赛胞内に分泌萻積されたCA19-9が内圧の克 進によって血中へ逸脱するものと推定されているが，

報告されている症例の多くで，衰胞被覆細胞の免疫染 色でCA19-9の陽性所見を認め, 儴胞摘出後に血清 CA19-9が正常化しているため,この推定を支持するも のと思われる。自験例に扔いても襄胞被覆細胞の免疫 染色にて CEA，CA19-9，CA125のいずれも陽性であ り，血清 CA19-9，CA125は術後正常化した。

治㙩法としては，悪性の可能性を完全には否定でき ないため，手術が選択されることが多い。実際，稀て はあるが悪性腫瘍の合併も報告されている7゙。従来開 腹下脾摘術が行われていたが,近年では低侵襲であり， 美容的でもある腹腔鏡下手術を施行した報告が增えて きており ${ }^{8}$ ，今後積極的に導入するべきであろう。脾摘 後の免疫能低下により重症感染症の頻度が增加すると の報告があり9，患者が小児であった場合は，なるべく 脾藏を温存することが望ましいとする報告が多い101. このため脾部分切除術 ${ }^{11}$ や售胞内容液の穿刺排液 ${ }^{121} の$ み, 穿刺後エタノール注入 ${ }^{13)}$, 穿刺後テトラサイクリン (TC) 注入(4)などを施行した報告例も認めた。しかし， これらの症例では再発が問題となっている，自験例て は篊胞が外傷性破裂しており，再破裂の危険性がある ことや，悪性腫癔である可能性を完全に否定できない ことから，手街を選択した，脾部分切除術を試みよう
としたが，裹胞があまりに巨大であり正常脾をほとん ど認めなかったため脾摘術となった。ただ，偶然副 脾を認めたため,これを大網内に移植した。術後経過 は良好で, 術後 1 年10力月後の現在まで重篤な感染症 は発症していない。

\section{結 語}

今回われわれは外傷による破裂を契機に発見され， 血清CA19-9およびCA125高值を呈した小児脾類表皮 豪胞の 1 例を経験したので報告した。

本論文の要旨は第64回日本臨床外科学会総会 (平成14年 11月13日，東京）にて発表した。

$$
\text { 文献 }
$$

1) Andral $G$ : Precis d'Anatomie pathologique. Vo12, Gabon, Paris, 1829, p432

2) McClure RD, Altermeiter WA:Cysts of the spleen. Ann Surg 116:98-102, 1942

3）田辺好英, 小柳泰久, 野牛道晃 他：小児脾致胞. 小児外科 $28: 343-347,1996$

4）山下芳的，島多勝夫，藤巻雅夫他：脾類表皮赛胞。 小児外科 $28: 396-404,1996$

5）大倉久直, 坂脇多津, 尾崎秀雄：糖鎖抗原 CA199ーエンザイムイムノアッセイとその臨床的意義 一。肝・胆・脺 $11: 21-28,1985$

6）島多勝夫，桐山誠一，山下芳朗地：血清 CA19-9高 值を呈した脾類表皮咅胞の1例.日消外会誌 $26: 942-946,1993$

7) Elit L, Aylward B:Splenic cyst carcinoma presenting in pregnancy. Am J Hematol $32: 57$ $-60,1989$

8）田中弘之, 谷口正次, 山本 淳他: Laparoscopic Dome Resectionを施行後に再発した真性脾蕉胞 の1例。外科 $63: 503-506,2001$ 
9) Buntain WL, Lynn HB: Splenorrhaphy: Changing concepts for the traumatized spleen. Surgery $86: 748-760,1979$

10）水野修吾, 須崎 真, 伊藤史人他：単発性脾裳演

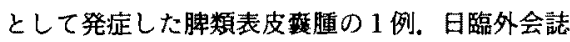
$60: 2726-2730,1999$

11) Brown MF, Ross AJ III, Bishop $\mathrm{HC}$, et al: Partial splenectomy: The preferred alternative for the treatment of splenic cysts. J Pediatr Surg 24: 694-696, 1989
12）山田拓司, 間下信昭, 大島充一他：血清 CA19-9が 高值を示した脾䓝胞の 1 例. 腹部画像猃断 14 ： $666-671,1994$

13）石丸英三郎，襄川公章，小野山裕彦他：血清 CA

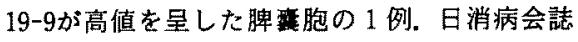
$96:$ A266, 1999

14) Yoshikane H, Suzuki T, Yoshioka N, et al: Giant splenic cyst with high serum concentration of CA19-9. Scand J Gastroenterol $31: 524$ $-526,1996$

\title{
A CASE OF TRAUMATIC RUPTURE OF A JUVENILE EPIDERMOID CYST OF THE SPLEEN WITH HIGH SERUM LEVELS OF CA 19-9 AND CA 125
}

\author{
Hiromasa YAMAMOTO ${ }^{122)}$, Tetsunobu UDAKA ${ }^{1)}$, Masaki TOKUMO \\ Minoru MIZUTA", Kazutoyo SHIRAKAWA ${ }^{11}$ and Takashi OHYA ${ }^{1 \prime}$ \\ "Department of Surgery, Mitoyo General Hospital \\ ${ }^{2}$ Department of Cancer and Thoracic Surgery, Graduate School of Medicine and Dentistry. Okayama University
}

We report a case of traumatic rupture of a juvenile epidermoid cyst of the spleen with high serum levels of CA 19-9 and CA 125. A 15-year-old man was admitted to the hospital because of an abdominal pain after a bruise. An abdominal CT scan revealed marked ascites and a ruptured large splenic cyst. A splenic angiography showed no extravasation and conservative treatment was made. The levels of serum CA $19-9$ and CA 125 were respectively as high as $214.5 \mathrm{U} / \mathrm{ml}$ and $221.5 \mathrm{U} / \mathrm{ml}$. Because other examinations showed no evidence of abnormalities in other organs, a splenectomy was performed under a preoperative diagnosis of an epidermoid cyst of the spleen. The levels of intracystic CEA, CA 19-9 and CA 125 were respectively as high as $383.9 \mathrm{ng} / \mathrm{ml},>5000.0 \mathrm{U} / \mathrm{ml}$ and $3041.1 \mathrm{U} / \mathrm{ml}$. Histological examination revealed that the inside of the cyst was covered with stratified squamous epithelium, and it was diagnosed as an epidermoid cyst of the spleen. On immunohistochemical stainings with anti-CEA, anti-CA 19-9, and anti-CA 125, the epithelium of the cyst revealed positive reactions. Postoperative course was uneventful. One month after the surgery, both levels of the elevated serum CA 19-9 and CA 125 were normalized. 